\title{
ОСОБЕННОСТИ СОСТАВА ТЕЛА БОЛЬНЫХ САХАРНЫМ ДИАБЕТОМ 2 ТИПА
}

\author{
1,2 Нагибович Г.П., 'Нагибович О.А., 'Монако Г.О. \\ ФГВБОУ ВО «Военно-медичинская академия им. С.М. Кирова» МО РФ, Санкт-Петербург \\ ООО «Балтийская медицинская клиника», Санкт-Петербург
}

ЦЕЛЬ: сравнить состав тела мужчин с сахарным диабетом (СД) 2 типа и лицами без нарушений углеводНого обмена.

МАТЕРИАЛЫ И МЕТОДЫ: проведено поперечное исследование амбулаторных пациентов - 24 мужчин с СД 2 типа (1-я группа). Группу сравнения (2-я группа) составили 41 мужчин без нарушений углеводного обмена, но с наличием ишемической болезни сердца. Пациенты были сопоставимы по основным антропометрическим показателям. Так, возраст больных 1-й группы составлял $65[61 ; 67]$ лет, во 2-й 65 [59; 71] лет; рост 174 [172; 178] см против 176 [171; 182] см. У больных СД гликированный гемоглобин $\left(\mathrm{HbA}_{1 c}\right)$ составил 7,7 [7,1;9,6]\%, расчетная скорость клубочковой фильтрации по формуле CKD-EPI $69[49 ; 81]$ мл/мин/1,73м², уровень альбумин-креатининового соотношения - 4,2 [1,1; 40,9] мг/ммоль. Состав тела человека оценивался аппаратным методом с помощью анализатора «InBody720» компании Biospace (Корея). Для анализа межгрупповых различий в независимых выборках использовался непараметрический критерий Манна-Уитни. Данные представлены в виде медианы и межквартильных интервалов Ме [HK; ВК]. Для выявления взаимосвязи между параметрами применяли коэффициент корреляции Спирмена (R). Различия считались статистически значимыми при $\mathrm{p}<0,05$. Обработка полученных результатов проводилась с использованием программных пакетов прикладных программ «Statistica 10.0» фирмы Statsoft Inc (США).

РЕзУЛЬтАТЫ: масса тела больных СД $(95,8$ [88,5; 106,9] кг) превышала таковую $(88,1$ [78,2; 95,7] кг, $\mathrm{p}=0,02)$ у лиц без нарушений углеводного обмена, подобная закономерность наблюдалась и для индекса массы тела (ИМТ) - 31,9 [30,1; 35,9] кг/м² против 28,3 [26,1;30,2] кг, p=0,001. Не было выявлено существенных различий по значениям внутриклеточной и внеклеточной воды, общей массе белка в организме, массе минералов и массе скелетных мышц. Обращало на себя внимание высокое содержание массы жировой ткани (МЖТ) в 1-й группе $(28,8$ [23,5;41,8] кг против $21,6[18,6 ; 31,0]$ кг, $\mathrm{p}=0,013)$, аналогичный результат обнаружен и при оценке площади висцерального жира (ПВЖ) (149 [122;189] см² против 115 [101; 145] см², $\mathrm{p}=0,016)$. Проведенный корреляционный анализ показал взаимосвязи $\mathrm{HbA}_{1 c}$ с ИMT $(\mathrm{R}=0,5, \mathrm{p}<0,05), \mathrm{M}$ ЖT $(R=0,55, p<0,05)$ и ПВЖ $(R=0,5, p<0,05)$.

Выводы: ожирение, сочетающееся с увеличенным отложением висцерального жира, выявляемые методом мультичастотной биоимпедансометрии, является отличительной особенностью состава тела мужчин, страдающих сахарным диабетом 2 типа. Ожирение ассоциировано с плохо корректирующейся гипергликемией, что оказывает неблагоприятное воздействие на пациента и должно учитываться при проведении патогенетической терапии сахарного диабета 2 типа.

КЛЮЧЕВЫЕ СЛОВА: сахарный диабет; висиеральное ожирение; мультичастотная биоимпедансометрия 